\title{
Autonomy of Nurses in Their Work and Associated Factors in Nurses of Selected Public Hospitals of Wollega Zones, Oromia Regional State, Western Parts of Ethiopia, 2020
}

\author{
Diriba Mulisa (D) \\ Tadesse Tolossa $\mathbb{D D}^{2}$ \\ Misganu Teshoma Regasa (D) \\ Lami Bayisa (D) \\ Tesfaye Abera' \\ Bizuneh Wakuma (iD ${ }^{3}$ \\ Alemnesh Mosisa ${ }^{\prime}{ }^{\prime}$ \\ 'School of Nursing and Midwifery, \\ Institute of Health Sciences, Wollega \\ University, Nekemte, Ethiopia; \\ ${ }^{2}$ Department of Public Health, Institutes \\ of Health Sciences, Wollega University, \\ Nekemte, Ethiopia; ${ }^{3}$ Department of \\ Pediatric nursing, Institutes of Health \\ Sciences, Wollega University, Nekemte, \\ Ethiopia
}

Correspondence: Diriba Mulisa School of Nursing and Midwifery, Institutes of Health Sciences, Wollega University, P.O.Box: 395, Nekemte, Ethiopia

Tel +251982725422

Email diribamilisa@gmail.com
Background: Nursing clinical autonomy is a decision made by the nurse about individual patient care independently. The development of the nursing profession needs an increment in nurses' autonomy in their work. Knowing the status of nursing autonomy and factors associated with it is recommended for developing nurses' profession. The aim of this study was to getthe status of nursing autonomy and associated factors.

Methods: An institution-based cross-sectional study was conducted among nurses working in selected public hospitals. For data entry, Epi Data version 3 was used and data was exported to Stata SE version 14 for analysis. To find the associated variables with the autonomy of nurses, bivariable and multivariable logistic regression methods were used. For this analysis, variables with a P-value of $\leq 0.25$ were candidates for multiple logistic regressions. To get the final variables, backward logistic regression model was used. Variables with a P-value of $\leq 0.05$ were considered as associated factors for the level of autonomy of nurses and the final finding was presented with a description, graph, and tables. Results: In this study, 349 nurses were involved in the study, and all have been participated and yielded a response rate of $100 \%$. Greater than half of nurses were male $188(53.87 \%)$. More proportion of the nurses have a working experience of less than six years (214 $(61.32 \%))$. Again, more proportion of nurses have not engaged in training focusing on the nursing profession $(208(59.60 \%))$. Greater than half of the nurses in this study have a poor level of autonomy regarding their work in the field of nursing profession (188 (53.87\%)). Factors contributing to a low level of autonomy among nurses are being older $\mathrm{AOR}=0.58$ $(95 \%$ CI $0.35,0.98)$ and not participate in a member of nurses' association AOR $=0.29(95 \%$ CI $0.14,0.61)$. Again, the finding showed that nurses who wish to stay in the nursing profession have a high level of nursing autonomy AOR=1.82, (95\% CI 1.09, 3.02).

Conclusion and Recommendation: Nurses' autonomy regarding their work is very low in the study area. Being relatively older, not participating in any nursing association, and having the intent to stay in the nursing profession are factors that affect nursing autonomy in their work. These contributing factors have to be identified and improved by concerned stakeholders in the health care system to improve nurses' autonomy in their works.

Keywords: autonomy, nursing, profession, Ethiopia

\section{Introduction}

Nurses' autonomy is the capacity of nurses to do what is expected from them without the needs of other parts' involvements. ${ }^{1-3}$ Nursing clinical autonomy is 
a decision made by nurses about individual patient care independently without taking permission from somebody. ${ }^{2}$ When nurses make patient management with their own knowledge and skill regarding the nursing profession, this is called nurses' autonomy. ${ }^{4}$ Autonomy is a fundamental concept in the nurses' profession, and a high level of autonomy brings good patient's outcomes. ${ }^{5}$ Nursing profession is autonomous and selfgoverning discipline. ${ }^{6}$

Some research findings showed that nursing autonomy in their field of work is limited that is there is a physician involvement. This showed that every duty conducted by nurses is supervised by doctors. ${ }^{1}$ Every profession has its own autonomy that shows liberty of the profession from others, and this autonomy is mostly not maintained in a nursing profession. ${ }^{1}$ Even, some nurses themselves believe that their autonomy is turned on and off, and they do not constantly maintain their professional autonomy. ${ }^{7}$

The nursing profession is a very important field in the health care system, and improvement in this field is directly related to improving health care delivery for patients. ${ }^{8}$ A development of nursing autonomy in their fields of work is a very important issue in developing nurses' profession. ${ }^{1}$ If the level of nursing autonomy increases, the profession will get high recognition and respect from the society, and this decreases the level of the nurse from the nursing profession. ${ }^{5}$ Research finding revealed that nurses who have a high level of autonomy have a high level of their own job satisfaction. ${ }^{9,10}$ If the nurse is satisfied with his/her work, he/she will give effective and efficient health care services for the patients and this brings improvement in the health care system.

The way of giving health care for the patient is a mutual effort of all health care workers. But, nurses play a great role in any health care services, and the role of nurses is also available with full responsibility. In this role and responsibility, there is a need for increment in autonomy among nurses regarding their role to make the patient become healthy. ${ }^{11}$

Some research findings also showed that lack of management support, hospital site, and failure in collaboration and teamwork, age of nurses, year of experience, educational background and currently assigned role are factors that affect the autonomy of nurses in a nursing profession. ${ }^{12-15}$ In the modern era, nurses' work is categorized into many relatively specific areas such as a medical ward, surgical ward, and others. Nurses working at the critical care unit or intensive care unit have a high level of autonomy as compared with other nurses. ${ }^{9}$

The level of professional autonomy among nurses can be measured in many ways. Some measures categorize the level of autonomy as high and low. Accordingly, a study conducted on Iranian nurses showed $66.7 \%$ of the nurses have a high level of autonomy regarding their works. ${ }^{14}$

Unless there is improvement in nurses' autonomy, there is no means by which developed nursing professionalism is achieved. Regarding nurses' autonomy in their work, there is no adequate finding especially in developing countries such as Ethiopia. Since nurses have a great role in health care services, it is must to develop the nursing profession, and this is achieved by increasing the autonomy of the nurses in their work. The aim of this study was to find the autonomy of the nurses and associated factors for the status of nursing autonomy.

\section{Method}

An institutional-based cross-sectional study was employed among nurses working in a selected public hospital of wollega zones. In western parts of Ethiopia, Wollega zones are located in the Oromia regional state. This specific region in Ethiopia has four zones and this research was conducted in three zones of this region. All nurses working in wollega zones hospitals were considered as a source population and those nurses who were available to participate in the study during the study period at the selected hospitals were considered as study population.

All nurses who were working in the hospitals for at least 6 months in the given hospitals were included in the study, while nurses who had worked in the hospital for less than 6 months were excluded from the study.

\section{Sample Size Determination}

In this study, the sample size was determined by the double population proportion formula. In this case, previously independent significant variables with autonomy of nurses were considered. Accordingly, the sex variable was considered to calculate the sample size. To get the final sample size, Epi Info version 7 was considered. Parameters as a proportion of outcome in female as an exposed group are $66.85 \%$ and male as a control group is $51.70 \%$. By using a $5 \%$ margin of error and $80 \%$ power, this sex variable yields the largest sample size that is 332 . Then, by adding $5 \%$ non-response rate the final sample size was 349 . Then, proportional allocation was computed for all involved hospitals Table 1. 
Table I Proportional Allocations of Nurses in Selected Public Hospitals of Wollega Zones, Oromia Regional State Ethiopia, 2020

\begin{tabular}{|l|l|l|l|}
\hline Hospitals & Number of Nurses They Have & Proportionally Accepted & Final sample size \\
349 \\
\hline Shambu General hospital & 55 & 39 & 122 \\
\hline Nekemte specialized hospital & 175 & 40 \\
\hline Nejo General Hospital & 57 & 101 \\
\hline Wollega University RTH & 145 & 26 \\
\hline Arjo hospital & 37 & 21 \\
\hline Sire hospital & 30 & \\
\hline
\end{tabular}

\section{Sampling Procedure}

To get the involved participants, a systematic sampling technique was used. In this case, to get each nurse, first ID number of nurses who have been working in the given hospital was identified. First, the lottery method was conducted for the patient ID who had registered on number one and two based on a list of the nurses' ID. Number. For all nurses in all included hospitals, this lottery method was made to get involved nurses. Then, starting from the accepted ID number by a lottery method the next nurse was selected by having passed on two nurses' ID number. When the selected nurse is not available due to many reasons during the study period, the next nurse was accepted. This was done until the required numbers of a nurse from the given hospitals were obtained for this study.

\section{Data Collection Tool and Technique}

The question has some parts as biographical and other nurse-related questions, and the Halls professionalism measuring items related to Believe in Autonomous. The Halls professionalism measuring has five dimensions of which each contains five items. Those items were measured on a five-point Likert scale. Respondents evaluated how well each statement corresponded to the way they felt and behaved, with responses ranging from 1 (Strongly disagree) to 5 (strongly agree). Higher scores were represented as nurses are having higher autonomy in their work related to their profession.

The data weres collected by two BSc nurses and one MPH holder as a supervisor for each hospital for 2 weeks. Self-answered questions were distributed for nurses. When the involuntary nurse appeared, the next nurse was asked.

To maintain data quality, the training was given to data collectors and supervisors for 1 day at another hospital.
The question was prepared in the English language. To maintain consistency with the question, pretest was conducted on $5 \%$ of the participants at Gida Ayana hospital. In the pretest, the question was evaluated for its internal consistency and the Cronbach's alpha value was 0.8 . The data collection was daily monitored by the supervisors.

\section{Data Processing and Analysis}

After being checked for completeness, data were entered into Epi Data version 3 and exported to STATA SE version 14 for analysis. Data were cleaned and edited by running simple frequencies and cross-tabulation before analysis. Mean with confidence interval and percentages were used to summarize the characteristics of every involved variable. For the autonomy, part questions mean values were computed.

The questions regarding autonomy have been dichotomized into good autonomy and poor autonomy based on the mean value. The mean score for this research was 3.29 for each nurse. Then good autonomy that is those who have scored greater than 3.29 is recoded as 1 and poor autonomy that is those who have scored $\leq 3.29$ was recoded as 0. Making this level of autonomy as a dependent variable, bivariable and multivariable logistic regressions were used to identify factors associated with nursing autonomy. Independent variables with a $\mathrm{p}$ value $\leq 0.25$ in the bivariate analysis were included in the multivariable analysis. The variable in the final model was selected by the stepwise backward selection procedure. Model of the goodness of fit was done by loglikelihood goodness-of-fit test. Crude odds ratio and adjusted odds ratio with $95 \%$ confidence intervals were computed and statistical significance variables were considered with $\mathrm{P}$-value $<0.05$. Then, the final finding was presented in tables and narrative description. 


\section{Results}

\section{Socio-Demographic Characteristics of the Nurses}

In this research, more proportion of the nurses is male 188 (53.87\%). Around three-fourth of the nurses are Protestant religion followers $261(74.79 \%)$. Greater than half of the nurses who participated in this study are married 229 $(65.62 \%)$. Regarding work experience, more than half of the participants have less than 6 years of working experiences $214(61.32 \%)$. Table 2

\section{Characteristics of the Participants Concerning Nursing Profession}

Regarding to self-updating by education, greater than half of the nurses have participated in increasing their level of education 222 (63.61\%). More proportion of nurses has not engaged in training focusing on the nursing profession 208 (59.60\%). Again, only 159 nurses (45.56\%) want to stay in the nursing professionalism. Almost all of the participants want to update their level of education in the future 339 (97.13\%) (Table 3).

\section{Believe in One's Own Professional} Autonomy

In this study, more than half of nurses have a poor level of autonomy regarding their work in the field of nursing profession $188(53.87 \%)$. Less than a quarter of participants strongly disagree with the view of "I have much opportunity to exercise my own judgment" 29 (8.31\%). Table 4

\section{Factors Associated with Autonomy of Nurses in Their Profession Works}

In this study, variables such as sex, participation in the training concerning nursing professionalism, year of experiences, age of the nurses, membership in Ethiopian nursing association, were entered into multivariable logistic regression and from them, some of the variables showed significant association with nursing autonomy.

Accordingly, the result indicated that there was a significant association between the age of the nurses and their autonomy. That is, nurses with age greater than 28 years were $42 \%$ less likely have good nursing autonomy (AOR 0.58, 95\% CI 0.35, 0.98). Again the finding showed that those nurses who are not in members of the nursing association are $71 \%$ less likely to have a good level of
Table 2 Socio-Demographic Characteristics of the Nurses in Selected Public Hospitals of Wollega Zones, Oromia Regional State of Ethiopia, 2020

\begin{tabular}{|c|c|c|c|}
\hline Variables & Option & Frequency & Percent \\
\hline \multirow[t]{2}{*}{ Sex } & Male & 188 & 53.87 \\
\hline & Female & 161 & 46.13 \\
\hline \multirow[t]{2}{*}{ Age } & $<28$ years & 206 & 59.03 \\
\hline & $\geq 28$ years & 143 & 40.97 \\
\hline \multirow[t]{4}{*}{ Religion } & Protestant & 261 & 74.79 \\
\hline & Orthodox & 69 & 19.77 \\
\hline & Muslim & 8 & 2.29 \\
\hline & Others & 11 & 3.15 \\
\hline \multirow[t]{3}{*}{ Marital status } & Single & 103 & 29.51 \\
\hline & Married & 229 & 65.62 \\
\hline & Widowed/divorced | & 17 & 4.87 \\
\hline \multirow[t]{8}{*}{ Current role } & Metron & 4 & 1.15 \\
\hline & $\begin{array}{l}\text { Medical and surgical } \\
\text { ward }\end{array}$ & 117 & 33.52 \\
\hline & OPD & 47 & 13.47 \\
\hline & Operation room & 92 & 26.36 \\
\hline & Emergency & 38 & 10.89 \\
\hline & Pediatric & 36 & 10.32 \\
\hline & Critical care & 7 & 2.01 \\
\hline & Others & 8 & 2.29 \\
\hline \multirow{2}{*}{$\begin{array}{l}\text { Education } \\
\text { level }\end{array}$} & Diploma & 106 & 30.37 \\
\hline & Degree & 243 & 69.63 \\
\hline \multirow[t]{2}{*}{ Experience } & $<6$ years & 214 & 61.32 \\
\hline & $\geq 6$ years & 135 & 38.68 \\
\hline \multirow[t]{2}{*}{ Salary } & $<5072$ ETB & 157 & 44.99 \\
\hline & $\geq 5072$ ETB & 192 & 55.01 \\
\hline
\end{tabular}

nursing autonomy in their works as compared with those who participated in nursing association AOR 0.29 (95\% CI $0.14,0.61)$. There was also a significant association between wish to stay in the nursing professionalism among nurses and nurses' autonomy. That is, nurses who wish to stay in the nursing profession are 1.82 times more having good nursing autonomy than those who do not want 
Table 3 Characteristics of the Nurses Concerning Their Profession in Selected Public Hospitals of Wollega Zones, Oromia Regional State Ethiopia, 2020

\begin{tabular}{|c|c|c|c|}
\hline Variables & Options & Frequency & Percent \\
\hline \multirow[t]{2}{*}{ Increase their education level } & Yes & 127 & 36.39 \\
\hline & No & 222 & 63.61 \\
\hline \multirow[t]{2}{*}{ Member in nurse association } & Yes & 48 & 13.75 \\
\hline & No & 301 & 86.25 \\
\hline \multirow[t]{2}{*}{ Participate in update training } & Yes & $|4|$ & 40.40 \\
\hline & No & 208 & 59.60 \\
\hline \multirow{2}{*}{$\begin{array}{l}\text { Is there support among } \\
\text { member }\end{array}$} & Yes & 248 & 71.06 \\
\hline & No & 101 & 28.94 \\
\hline \multirow{2}{*}{$\begin{array}{l}\text { Bothered from lack of } \\
\text { material during work }\end{array}$} & Yes & 258 & 73.93 \\
\hline & No & 91 & 26.07 \\
\hline \multirow{2}{*}{$\begin{array}{l}\text { Wish to stay in nursing } \\
\text { professionalism }\end{array}$} & Yes & 159 & 45.56 \\
\hline & No & 190 & 54.44 \\
\hline \multirow{2}{*}{$\begin{array}{l}\text { Do you Wish further } \\
\text { education }\end{array}$} & Yes & 339 & 97.13 \\
\hline & No & 10 & 2.87 \\
\hline \multirow{2}{*}{$\begin{array}{l}\text { Which field do you want to } \\
\text { learn }\end{array}$} & Nursing & 160 & 47.20 \\
\hline & $\begin{array}{l}\text { Other } \\
\text { fields }\end{array}$ & 179 & 52.80 \\
\hline
\end{tabular}

to stay in the nursing profession (AOR1.82, 95\% CI 1.09, 3.02) (Table 5)

\section{Discussion}

Currently, the need for improvement in health care is high, but regarding nurses' autonomy in their work, there is no more concern. Nursing clinical autonomy is a decision made by the nurses about individual patient care. ${ }^{2}$ The aim of this study was to identify the level of nurses' autonomy in their works and factors associated with it.

The result revealed that greater than half of the nurses have a low level of autonomy in their works. That is, $53.87 \%$ of the nurses have a low level of autonomy regarding their work. But, a study conducted in Iranian nurses showed that greater than half of the nurses have
Table 4 Believe in One's Own Professional Autonomy Among Nurses Working in Selected Public Hospitals of Wollega Zones, Oromia Regional State Ethiopia, 2020

\begin{tabular}{|c|c|c|c|}
\hline Variables & Option & Frequency & Percent \\
\hline \multirow[t]{2}{*}{ Nursing autonomy } & Good & 161 & 46.13 \\
\hline & Poor & 188 & 53.87 \\
\hline \multirow{5}{*}{$\begin{array}{l}\text { I make my own } \\
\text { decisions in regarding } \\
\text { what is going to be } \\
\text { done in my work }\end{array}$} & $\begin{array}{l}\text { Strongly } \\
\text { disagree }\end{array}$ & 22 & 6.30 \\
\hline & Disagree & 18 & 5.16 \\
\hline & Neutral & 82 & 23.50 \\
\hline & Agree & 112 & 32.09 \\
\hline & Strongly agree & 115 & 32.95 \\
\hline \multirow{5}{*}{$\begin{array}{l}\text { I know that my own } \\
\text { judgment on any } \\
\text { matter is the final } \\
\text { judgment }\end{array}$} & $\begin{array}{l}\text { Strongly } \\
\text { disagree }\end{array}$ & 76 & 21.78 \\
\hline & Disagree & 72 & 20.63 \\
\hline & Neutral & 104 & 29.80 \\
\hline & Agree & 58 & 16.62 \\
\hline & Strongly agree & 39 & 11.17 \\
\hline \multirow{5}{*}{$\begin{array}{l}\text { I have much } \\
\text { opportunity to exercise } \\
\text { my own judgment }\end{array}$} & $\begin{array}{l}\text { Strongly } \\
\text { disagree }\end{array}$ & 29 & 8.31 \\
\hline & Disagree & 34 & 9.74 \\
\hline & Neutral & 162 & 46.42 \\
\hline & Agree & 76 & 21.78 \\
\hline & Strongly agree & 48 & 13.75 \\
\hline \multirow{5}{*}{$\begin{array}{l}\text { My own decisions are } \\
\text { not subject to review } \\
\text { by other peoples }\end{array}$} & $\begin{array}{l}\text { Strongly } \\
\text { disagree }\end{array}$ & 21 & 6.02 \\
\hline & Disagree & 48 & 13.75 \\
\hline & Neutral & 122 & 34.96 \\
\hline & Agree & 99 & 28.37 \\
\hline & Strongly agree & 16.91 & 16.91 \\
\hline \multirow{5}{*}{$\begin{array}{l}\text { I have no enforcing } \\
\text { boss in almost every } \\
\text { work-related my scope } \\
\text { of work. }\end{array}$} & $\begin{array}{l}\text { Strongly } \\
\text { disagree }\end{array}$ & 17 & 4.87 \\
\hline & Disagree & 16 & 4.58 \\
\hline & Neutral & 43 & 12.32 \\
\hline & Agree & 90 & 25.79 \\
\hline & Strongly agree & 183 & 52.44 \\
\hline
\end{tabular}


Table 5 Multivariable Analysis of Factors Associated with Nursing Autonomy Among Nurses Working in Selected Public Hospitals of Wollega Zones, Oromia Regional State Ethiopia, 2020

\begin{tabular}{|c|c|c|c|c|c|c|}
\hline \multicolumn{2}{|l|}{ Characteristics } & \multicolumn{2}{|c|}{ Autonomy } & \multirow{2}{*}{$\begin{array}{l}\text { COR } \\
(95 \% \mathrm{CI})\end{array}$} & \multirow{2}{*}{$\begin{array}{l}\text { AOR } \\
(95 \% \mathrm{Cl})\end{array}$} & \multirow[t]{3}{*}{ P-value } \\
\hline & & \multirow{2}{*}{$\begin{array}{l}\text { Good } \\
102 \\
(29.22)\end{array}$} & \multirow{2}{*}{$\begin{array}{l}\text { Poor } \\
104 \\
(29.79)\end{array}$} & & & \\
\hline Age of the nurses & $\leq 28$ & & & & & \\
\hline & $>28$ & $59(16.90)$ & $84(24.06)$ & $0.71(0.46,1.10)$ & $0.58(0.35,0.98)$ & $0.04 *$ \\
\hline \multirow[t]{2}{*}{ Sex } & Male & $81(23.20)$ & $\begin{array}{l}107 \\
(30.65)\end{array}$ & \multicolumn{3}{|l|}{ I } \\
\hline & Female & $80(22.92)$ & $81(23.20)$ & $1.30(0.85,1.99)$ & I.76 (0.7I, I.77) & 1.12 \\
\hline \multirow{2}{*}{$\begin{array}{l}\text { Membership in Ethiopian Nursing association or } \\
\text { other else }\end{array}$} & Yes & $31(8.88)$ & $17(4.87)$ & I & & \\
\hline & No & $\begin{array}{l}130 \\
(37.24)\end{array}$ & $\begin{array}{l}171 \\
(48.99)\end{array}$ & $0.4 I(0.22,0.78)$ & $0.29(0.14,0.61)$ & $<0.01 *$ \\
\hline \multirow[t]{2}{*}{ Wish to stay in nursing professionalism } & Yes & $83(23.78)$ & $74(21.20)$ & $1.56(1.02,2.39)$ & $1.82(1.09,3.02)$ & 0.021 \\
\hline & No & $78(22.34)$ & $\begin{array}{l}138 \\
(39.54)\end{array}$ & & & \\
\hline \multirow[t]{2}{*}{ Is there support among member } & Yes & $\begin{array}{l}114 \\
(32.66)\end{array}$ & $\begin{array}{l}134 \\
(38.39)\end{array}$ & \multicolumn{3}{|l|}{ I } \\
\hline & No & $47(13.46)$ & $54(15.47)$ & $\mathrm{I} .02(0.64, \mathrm{I} .62)$ & $0.77(0.43,1.36)$ & 0.37 \\
\hline \multirow[t]{2}{*}{ Participate on training } & Yes & $68(19.48)$ & $73(20.91)$ & & & \\
\hline & No & $93(6.64)$ & $\begin{array}{l}115 \\
(32.95)\end{array}$ & $0.86(0.56,1.33)$ & $0.78(47,1.30)$ & 0.35 \\
\hline \multirow[t]{2}{*}{ Experience in nursing works } & $<6$ & $99(28.36)$ & $\begin{array}{l}115 \\
(32.95)\end{array}$ & & & \\
\hline & $\geq 6$ & $62(17.76)$ & $73(20.91)$ & $0.98(0.64, I .5 \mathrm{I})$ & $1.37(0.80,2.34)$ & 0.24 \\
\hline
\end{tabular}

Note: *Significant association.

a high level of autonomy in their work $(66.7 \%)^{14}$ and again high in America, Florida and in New york. ${ }^{16,17}$ The discrepancy in the level of autonomy among those study may be due to many reasons such as differences by level of the economy, education status, the salary of the nurses, and social acceptability of the profession. That is, in Iran and developed countries they can give an adequate salary and the required material for the nurses. Again, developed countries have relatively delivered appropriate education for their nursing students during their study. If the development of the nursing profession is needed in Ethiopia, there must be a strategy to increase nurses' autonomy that is good for patients' positive outcomes.

Regarding the factors associated with the level of autonomy among nurses, finding from this study showed that being relatively younger is associated with having a high level of autonomy than older nurses. This study is also supported with a study conducted in Iran's nurses. ${ }^{14}$ This may be due to those relatively younger nurses have learned with the recent modern curriculum and with a modern resource for learning materials. Again, the younger nurses update themselves more than older nurses, and this gives them high confidence in their work. Having high confidence encourages nurses to develop independent autonomy in their work.

Again, this research finding showed that being a member of any nursing association is significantly associated with increasing the autonomy of the nurses in their field of work. This may be due to participating in the association encouraging their members so that they have self-confidence in their works that leads to a high level of autonomy. Ethiopian nursing association helps its 
members in many ways such as giving training to their member, updating their education level, creating means of getting a scholarship for their member, and standing for the right of its members. ${ }^{18}$ And that is why those individuals have a high level of nursing autonomy in their work area than those who do not participate in any nursing association. This association is common in developing countries such as Canada, Iran, and America. That is why their nursing professionals have good autonomy in their works. ${ }^{19}$ Being a member of a nursing association is better to encourage nursing autonomy in their work.

Those nurses who wish to stay in the nursing profession have a high level of autonomy in their work than those who do not wish to stay in the nursing profession. In Ethiopia, there is a high number of nurses who leave the profession and go to join another profession. If there is no wish to stay in the profession, there will be no appetite to develop self-competent, and this will lead to having a low level of autonomy. Research finding showed that intent to stay in the nursing profession is very low in developing countries. $^{20,21}$

\section{Conclusion}

Nursing autonomy regarding their work is very low in the study area. Being relatively older, not participating in any nursing association, and having the intent to stay in the nursing profession are factors that affect nurses' autonomy in their work. These contributing factors have to be identified and improved by concerned stakeholders in the health care system, to improve nurses' autonomy.

\section{Recommendation}

If there is a need for increasing the quality of nursing services in the health care system, it is a must to improve nurses' autonomy in their work. To increase nurses' autonomy, the following stakeholders are expected to play their role!

Nurses themselves: It is better if the nurses are participating in any association that works on behalf of the nurse profession. Again, they have to have the intent to stay in their profession and have full willingness to participate in their work.

Health care institutions/hospitals: Health care institutions and hospitals are expected to create means of increasing nursing autonomy in their work that is by giving training for the nurses, giving an opportunity for them to participate in the association, encourage them to get the chance of updating themselves.
Nursing association/any stakeholder: The nurses' association has to be inclusive, that is every nurse in the country has to participate in it. Those associations have to encourage nurses by creating scholarship opportunities, debating for their rights if disturbed, and fully standing for the nurses.

\section{Limitation of the Study}

Since this study is quantitative, it is better to compile a qualitative study design. Again, the method used in this study was binary logistic regression and it is better if other research is conducted using linear regression at different study areas by other researchers on a large sample size.

\section{Abbreviations}

AOR, adjusted odds ratio, COR, crude odds ratio; OPD, outpatient departments.

\section{Data Sharing Statement}

The source of the data is present at corresponding author upon reasonable requested by concerned individuals.

\section{Ethical Considerations}

Ethical clearance was obtained from the Ethical review committee of Wollega University, Institute of Health Sciences. Formal letter that explains the objectives, rationale and expected outcomes of the study was explained for study area. Then, informed consent was obtained from the hospitals to allow the study in their hospital. Again written informed consent was obtained from all participated nurses and confidentiality of the information was maintained by omitting the names and personal identification. The anonymity and confidentiality of the responses was protected. The question was asked after the nurses' voluntary have been obtained. This research manuscript fulfilled the criteria of Declaration of Helsinki.

\section{Acknowledgments}

We would like to thank Wollega University for its support in conducting this research by many directions

\section{Author Contributions}

All authors made a significant contribution to the work reported, whether that is in the conception, study design, execution, acquisition of data, analysis and interpretation, or in all these areas; took part in drafting, revising or critically reviewing the article; gave final approval of the version to be published; have agreed on the journal to 
which the article has been submitted; and agree to be accountable for all aspects of the work.

\section{Disclosure}

The authors report no conflicts of interest in this work.

\section{References}

1. Florentino TC, Mascarenhas NB, Macedo KS, Silva M, Mascarenhas SN. Professional autonomy of the nurse: some reflections. EEAN. 2016.

2. Marla W. Defining control over nursing practice and autonomy. J Nurs Adm. 2008;38(9):9.

3. Dos Santosa ÉI, Alvesa YR, da Silvaa AC, Gomes AM. Professional autonomy and nursing: representations of health professionals. Rev Gaúcha Enferm. 2017;38(1):e59033.

4. Kramer MS. Magnet hospital nurses describe control over nursing practice. West J Nurs Res. 2003;25:434-452. doi:10.1177/ 0193945903025004008

5. Heale R Benefits of nursing autonomy; 2017. Available from: https:// blogs.bmj.com/ebn/2017/08/20/benefits-of-nursing-autonomy/. Accessed May 21, 2021.

6. Nursing Tta. Are you sure nurses are autonomous? Based on what I've seen, it sure looks like physicians are calling the shots; 2020. Available from: https://www.truthaboutnursing.org/faq/autonomy.html\#gsc.tab= 0. Accessed May 21, 2021.

7. Oshodi TO, Bruneau B, Crockett R, Kinchington F, Nayar S, West E. Registered nurses' perceptions and experiences of autonomy: a descriptive phenomenological study. BMC Nurs. 2019;18(1). doi:10.1186/s12912-019-0378-3

8. University M. Why nurses are important in healthcare and you should become an RN. Atlanta, Georgia; 2019. Available from: https://absn. mercer.edu/blog/why-nurses-are-important-in-healthcare/. Accessed May 21, 2021.

9. Taylor MA. The relationship between autonomy and job satisfaction among registered nurses; 2008.
10. Mrayyan M. Nurses' autonomy: influence of nurse managers' actions. $J$ Adv Nurs. 2018;45(3):326-336. doi:10.1046/j.13652648.2003.02893.x

11. Tarkkanen K, Reijonen P, Harkke V. Roles and identification of stakeholders in health care IS development; 2013.

12. Valizadeh L, Zamanzadeh V, Shohani M. Challenges of autonomy in nursing: an integrative review. $Q J$ Nurs Manag. 2013;2(1):9-17.

13. Supametaporn P. The conceptualization of professional nurse autonomy. Jpn J Nurs Sci. 2013;31(1).

14. Shohani M, Rasouli M, Sahebi A. The level of professional autonomy in Iranian nurses. J Clin Diagn Res. 2018;12(5).

15. Ten Hoeve Y, Jansen G, Roodbol P. The nursing profession: public image, self-concept and professional identity A discussion paper. J Adv Nurs. 2014;70(2):295-309. doi:10.1111/jan.12177

16. Alex Bahadori J, Fitzpatrick J. Level of autonomy of primary care nurse practitioners. J Am Acad Nurse Pract. 2008;21:513-519. doi:10.1111/j.1745-7599.2009.00437.x

17. Cajulis C, Fitzpatrick J. Levels of autonomy of nurse practitioners in an acute care setting. J Am Acad Nurse Pract. 2007;19(1-8). doi:10.1111/j.1745-7599.2007.00257.x

18. Association En. Latest jobs from Ethiopian Nurses Association. Addis Ababa: Regulation \& Capacity Building Advisor; 2020. Available from: https://milkta.com/en/jobs-by-company/2437/ethio pian-nurses-association. Accessed May 21, 2021.

19. ANA. American Nurses Association; 2020. Available from: https:// journals.lww.com/ajnonline/fulltext/2006/01001/american_nurses_ association.2.aspx. Accessed May 21, 2021.

20. Engeda EH, Birhanu AM, Alene KA. Intent to stay in the nursing profession and associated factors among nurses working in Amhara Regional State Referral Hospitals, Ethiopia. BMC Nurs. 2014;13(24). doi:10.1186/1472-6955-13-24

21. Ahmed R, Abdelwahab E, Elguindy H. Staff nurses' intention to leave nursing profession and their organizational commitment in selected hospitals at Beni-Suef city. Egypt Nurs J. 2017;14(1):17. doi:10.4103/2090-6021.206940
Nursing: Research and Reviews

\section{Publish your work in this journal}

Nursing: Research and Reviews is an international, peer-reviewed, open access journal publishing original research, reports, reviews and commentaries on all aspects of nursing and patient care. These include patient education and counseling, ethics, management and organizational issues, diagnostics and prescribing, health outcomes, economics and resource management, improving patient safety in all settings. The manuscript management system is completely online and includes a very quick and fair peer-review system. Visit http://www. dovepress.com/testimonials.php to read real quotes from published authors. 